\title{
Detection of high levels of congenital transmission of Toxoplasma gondii in natural urban populations of Mus domesticus
}

\author{
P. A. MARSHALL ${ }^{1}$, J. M. HUGHES ${ }^{2}$, R. H. WILLIAMS ${ }^{2}$, J. E. SMITH' ${ }^{3}$, R. G. MURPHY ${ }^{1}$ \\ and $\mathrm{G} . \mathrm{HIDE}^{2 *}$ \\ ${ }^{1}$ Built and Human Environment Research Institute, School of Environment and Life Sciences, University of Salford, \\ Salford M5 4WT, UK \\ ${ }^{2}$ Centre for Parasite Biology, Molecular Epidemiology and Ecology, Biosciences Research Institute, School of Environment and \\ Life Sciences, University of Salford, Salford M5 4WT, UK \\ ${ }^{3}$ School of Biology, University of Leeds, Leeds LS2 97T, UK
}

(Received 15 March 2003; revised 18 fuly 2003; accepted 29 fuly 2003)

\section{SUMMARY}

The relative importance of different transmission routes of Toxoplasma gondii has been a matter for debate. This ubiquitous parasite is generally thought to be transmitted by infective oocysts excreted by the definitive host, the cat. Ingestion of undercooked meat has also been considered an important route of transmission in many mammals while congenital transmission has generally been considered relatively rare. Experimental studies demonstrate the ability of $T$. gondii to be transmitted congenitally, but few studies have investigated the frequency of this transmission route in natural populations. We use PCR amplification of the SAG1 gene to investigate the frequency of congenital transmission in a wild population of mice (Mus domesticus) and show that congenital transmission is occurring in $75 \%$ of pregnancies in this population. Furthermore, for infected pregnant mice, transmission occurs to at least one foetus in $100 \%$ of cases while variable penetrance of congenital infection is observed. These high levels of congenital transmission in this wild population of mice, taken together with other recent data on congenital transmission in sheep, suggests that this phenomenon might be more widespread than previously thought.

Key words: Toxoplasma gondii, Mus domesticus, PCR, SAG1, congenital, transmission.

\section{INTRODUCTION}

Toxoplasma gondii is widespread, infecting many mammals including humans and causing congenital disease and abortion in some species, notably humans and sheep. The cat is the definitive host and is the only animal that can host the sexual stage of the parasite. As the infective oocysts excreted by the cat are considered a major source of infection, the advice typically given to pregnant women and livestock farmers focuses on the avoidance of contact with cats. The ingestion of undercooked meat is also believed to be a major source of infection in omnivores and carnivores while congenital transmission, although known to occur, is considered less important. Figures for congenital transmission in humans, for example, are found to range between $0 \cdot 01$ and $1 \%$ (Tenter et al. 2000). The notion that this route of transmission may be important in mammals has been controversial (Johnson, 1997). Experimental infection of the house mouse (Mus domesticus) and the field mouse (Apodemus sylvaticus) with infective oocysts demonstrated

* Corresponding author: Biosciences Research Institute, School of Environment and Life Sciences, University of Salford, Salford M5 4WT, UK. Fax: +0161 2955015. E-mail: g.hide@salford.ac.uk a high frequency of vertical transmission of $T$. gondii (Owen \& Trees, 1998). Furthermore, other experimental studies document congenital transmission in mice (e.g. Elsaid et al. 2001; Stahl, Sekiguchi \& Kaneda, 2002). However, the frequency of vertical transmission in natural populations of mammals has only been addressed in one study to date. In that study, we detected high levels of congenital transmission in a commercial sheep population (Duncanson et al. 2001) where the parasite was transmitted congenitally in $61 \%$ of lambings. That study suggested that this mode of transmission in natural populations might be much more significant than previously thought. Although the results of that study were unequivocal, the possibility existed that these high levels of congenital transmission may be either unique to sheep or a feature of a managed population. Furthermore, sheep possess a different placental anatomy and physiology to many other mammals, including mice, thus bringing into question the general applicability of this result. We address these questions by investigation of a natural population in another mammalian species. We report a high frequency of transmission in a wild urban population of the domestic mouse, $M$. domesticus, and consider the implications of this phenomenon in mammals. 
Table 1. Summary of the results of the analysis of pregnant mice for infection with Toxoplasma gondii

(Infected mice were defined as those from which an amplified SAG gene product was obtained. Congenital transmission (per pregnancy) was defined as those pregnancies where at least 1 foetus was infected.)

\begin{tabular}{lllllll}
\hline \hline & $\begin{array}{l}\text { No. of } \\
\text { pregnant } \\
\text { females }\end{array}$ & $\begin{array}{l}\text { Congenital } \\
\text { transmission } \\
\text { per pregnancy }\end{array}$ & $\begin{array}{l}\text { No. of } \\
\text { foetuses }\end{array}$ & $\begin{array}{l}\text { No. of } \\
\text { infected } \\
\text { foetuses }\end{array}$ & $\begin{array}{l}\text { Frequency of } \\
\text { transmission } \\
\text { (\% per pregnancy) }\end{array}$ & $\begin{array}{l}\text { Foetuses } \\
\text { infected }(\%)\end{array}$ \\
\hline Infected & 12 & 12 & 63 & 47 & 100 & $74 \cdot 6$ \\
Uninfected & 4 & 0 & 15 & 0 & 0 & 0 \\
Total & 16 & 12 & 78 & 47 & 75 & $60 \cdot 2$ \\
\hline \hline
\end{tabular}

Table 2. The infection status of foetuses for individual pregnancies

\begin{tabular}{llllll}
\hline \hline $\begin{array}{l}\text { Pregnant } \\
\text { mouse } \\
\text { number }\end{array}$ & $\begin{array}{l}\text { Infection } \\
\text { status of mother } \\
\text { (by SAG PCR) }\end{array}$ & $\begin{array}{l}\text { Total no. of } \\
\text { foetuses }\end{array}$ & $\begin{array}{l}\text { Infected } \\
\text { foetuses }\end{array}$ & $\begin{array}{l}\text { Uninfected } \\
\text { foetuses }\end{array}$ & $\begin{array}{l}\text { Foetuses } \\
\text { infected (\%) }\end{array}$ \\
\hline 1 & + & 3 & 2 & 1 & $66 \cdot 6$ \\
2 & + & 4 & 3 & 1 & 75 \\
3 & - & 3 & 0 & 3 & 0 \\
4 & + & 3 & 3 & 0 & 100 \\
5 & + & 7 & 7 & 0 & 100 \\
6 & - & 1 & 0 & 1 & 0 \\
7 & + & 9 & 9 & 0 & 100 \\
8 & + & 4 & 2 & 2 & 50 \\
9 & + & 6 & 3 & 3 & 50 \\
10 & + & 4 & 3 & 1 & 75 \\
11 & - & 6 & 0 & 6 & 0 \\
12 & + & 7 & 4 & 3 & $57 \cdot 1$ \\
13 & + & 5 & 5 & 0 & 100 \\
14 & - & 5 & 0 & 5 & 0 \\
15 & + & 6 & 5 & 1 & $83 \cdot 3$ \\
16 & + & 5 & 1 & 4 & 20 \\
Total & & 78 & 47 & 31 & $60 \cdot 2$ \\
\hline \hline
\end{tabular}

\section{MATERIALS AND METHODS}

Mice (Mus domesticus) were trapped inside residential houses in the Cheetham Hill area of Greater Manchester, UK, during the period January-May 2002. Live trapping formed part of a pest reduction programme and all animals were despatched using cervical dislocation. Brain samples were dissected using aseptic techniques from pregnant adult female mice. Foetuses were dissected from pregnant mice and washed extensively prior to removal from amniotic sacs. Internal tissues (brain) were extracted from the majority of isolated foetuses when size allowed. Smaller foetuses were washed extensively to remove any traces of maternal material. Samples were frozen until DNA extraction could be performed. DNA extraction was carried out as described previously (Terry et al. 2001).

Detection of Toxoplasma was carried out using the nested polymerase chain reaction (PCR) amplification of the Surface Antigen Gene 1 (SAG1) (Savva et al. 1990) as described previously (Duncanson et al. 2001). Samples that showed no amplification products were checked for the ability to amplify using primers to mouse tubulin as described (Terry et al. 2001) and were rechecked for SAG1 amplification using higher and lower DNA concentrations to ensure true negativity. PCR products were separated on $1.5 \%(\mathrm{w} / \mathrm{v})$ agarose gels containing $0.5 \mu \mathrm{g} / \mathrm{ml}$ ethidium bromide. DNA was separated by electrophoresis at $110 \mathrm{~V}$ for $60 \mathrm{~min}$ in $1 \times$ TBE buffer. After electrophoresis, gels were visualized by UV light transillumination using a Flowgen Alpha 1220 imaging system.

\section{RESULTS}

In total, 200 mice were trapped from within houses in the Cheetham Hill area of Manchester, UK. The overall prevalence for $T$. gondii was $59 \%$ for this set of mice. In this sample there were 16 pregnant females. SAG1 PCR amplification demonstrated that 12 of the pregnant females were infected with Toxoplasma thus giving a prevalence of $75 \%$ in this group. Of those 12 infected females, all 12 possessed at least 1 infected foetus and thus the overall frequency at which congenital transmission was occurring in this population of females was $75 \%$. Table 1 presents a summary of the infection status of female mice and foetuses examined in the study. The incidence of materno-foetal transmission was very high in the 
infected female mice $(n=12)$, there was evidence of transmission to at least 1 of the foetuses in all pregnancies although transmission to all foetuses occurred in only 4 females. As expected, there was no evidence of Toxoplasma infection in the foetuses derived from uninfected mice. There was individual variation in the transmission efficiency to offspring as shown in Table 2 which summarizes the results for individual pregnancies. On average, only $60 \cdot 2 \%$ of foetuses became infected and penetration of infection to foetuses was variable (ranging from 20 to $100 \%)$.

\section{DISCUSSION}

The prevalence of $T$. gondii in mammalian hosts is typically high with average prevalences around 30$40 \%$ and occasionally recorded levels of over $90 \%$ have been observed in some mammalian populations (including humans) (Tenter et al. 2000). The main routes of transmission which maintain these high prevalence levels are proposed to be infection by oocysts from the cat and carnivory of infected hosts (Blewett \& Trees, 1987; Dubey \& Beattie, 1988; Buxton, 1998; Tenter et al. 2000). The role of the cat in transmission has been questioned in part because the infective state only occurs for around 2 weeks as a kitten and therefore all infective oocysts must be released during this period. There is little evidence to link infection with exposure to cats and in herbivores, which are unable to acquire the disease by carnivory, the high prevalence is therefore perplexing. These arguments have promoted the idea that other routes of transmission may also be significant (Duncanson et al. 2001). Congenital transmission of $T$. gondii in mammalian hosts has been known for many years although it is generally considered to be relatively rare (Tenter et al. 2000). The notion that vertical transmission in Toxoplasma may be more important than previously thought (Johnson, 1997) has proved contentious as judged by the stress placed on the importance of the cat in the scientific literature (Blewett \& Trees, 1987; Buxton, 1998; Tenter et al. $2000)$ and in popular veterinary advice given to domestic animal farmers (e.g. Henderson, 1990). However, experimental studies on mice (Owen \& Trees, 1998) have shown that vertical transmission can occur at high frequency. Furthermore, vertical transmission of the closely related parasite Neospora has been demonstrated in mice (Cole et al. 1995), cattle (Bjorkman et al. 1996), dogs (Barber \& Trees, 1998) and foxes (Schares et al. 2001). The only study, to date, to have investigated this mode of transmission for Toxoplasma in a natural mammalian population (sheep) showed that high levels (61\%) of congenital transmission occurs (Duncanson et al. 2001). That study was focussed on a single farm and these high levels of transmission could have been due to an unusual feature of this farm, a peculiarity associated with a managed population or a species-specific effect associated with sheep.

In the current study, we report high levels of congenital transmission in a wild population of mice with $75 \%$ of female mice transmitting parasites to foetuses prior to birth. This is in concordance with experimental infection data (Owen \& Trees, 1998) where vertical transmission was reported in $85 \%$ of cases and in $100 \%$ of litters. The data reported in this paper, taken alongside experimental infection data in mice, support the results previously reported for sheep (Duncanson et al. 2001) and suggest that high levels of congenital transmission may be more widespread than previously thought. Acquisition of maternal infection could come from 2 sources: infection acquired during pregnancy or vertical transmission. In a natural population it is not possible to directly determine which is the case although experimental infection studies that have established that vertical transmission can occur in mice (Owen \& Trees, 1998) would support the latter mechanism. Furthermore, Duncanson et al. (2001) demonstrated that a consequence of high levels of congenital transmission in sheep was a high frequency of infected lambs that were born healthy and survived with no apparent effects of the parasite. This raises the possibility that infection could persist, for example as a dormant cyst state, with reactivation occurring as a result of immunosuppression during pregnancy thus offering a mechanism for vertical transmission. Further work is needed to address these questions and also to address the question of whether high levels of congenital transmission might be common in a wider variety of mammalian species.

We gratefully acknowledge funding from the Wellcome Trust, the University of Salford and the Cheetham and Broughton SRB. We thank Phil Duncanson for helpful discussions.

\section{REFERENCES}

BARbER, J. S. \& TREES, A. J. (1998). Naturally occurring vertical transmission of Neospora caninum in dogs. International Fournal for Parasitology 28, 57-64.

BJORKMAN, C., JOHANSSON, O., STENLUND, s., HOLMDAHL, O. J. \& UGGLA, A. (1996). Neospora species infection in a herd of dairy cattle. Fournal of the American Veterinary Medical Association 208, 1441-1444.

BLEWETT, D. A. \& TREES, A. J. (1987). The epidemiology of ovine toxoplasmosis with especial respect to control. British Veterinary fournal 143, 128-135.

BUXTon, D. (1998). Protozoan infections (Toxoplasma gondii, Neospora caninum and Sarcocystis spp.) in sheep and goats: recent advances. Veterinary Research 29, 289-310.

COlE, R. A., Lindsay, D. S., BLAGBURN, B. L. \& DUBEY, J. P. (1995). Vertical transmission of Neospora caninum in mice. Fournal of Parasitology 81, 730-732.

Dubey, J. P. \& BeATtie, C. P. (1988). Toxoplasmosis of Animals and Man. CRC Press, Boca Raton, Fl, USA. 
DUNCANSON, P., TERRY, R. S., SMITH, J.E. \& HIDE, G. (2001).

High levels of congenital transmission of Toxoplasma gondii in a commercial sheep flock. International Fournal for Parasitology 31, 1699-1703.

ELSAID, M. M. A., MarTins, M. S., FREZARD, F., BRAGA, E. M., \& VITOR, R. W. A. (2001). Vertical toxoplasmosis in a murine model, protection after immunization with antigens of Toxoplasma gondii incorporated into liposomes. Memorias do Instituto Oswaldo Cruz 96, 99-104.

HENDERSON, D. C. (1990). The Veterinary Book for Sheep Farmers. Farming Press, Ipswich.

JOHNSON, A. M. (1997). Speculation on possible life cycles for the clonal lineages in the genus Toxoplasma.

Parasitology Today 13, 393-397.

OWEN, M. R. \& TREES, A. J. (1998). Vertical transmission of Toxoplasma gondii from chronically infected house (Mus musculus) and field (Apodemus sylvaticus) mice determined by polymerase chain reaction. Parasitology 116, 299-304.
SAVVA, D., MORRIS, J. C., JOHNSON, J. D. \& HOLLIMAN, R. E. (1990). Polymerase chain reaction for detection of Toxoplasma gondii. Fournal of Medical Microbiology 32, 25-31.

SCHARES, G., WENZEL, U., MUller, T. \& CONRATHS, F. J. (2001). Serological evidence for naturally occurring transmission of Neospora caninum among foxes (Vulpes vulpes). International Fournal for Parasitology 31, 418-423.

STAHL, W., SEKIGUCHI, M. \& KANEDA, Y. (2002).

Cerebellar anomalies in congenital murine toxoplasmosis. Parasitology Research 88, 507-512.

TENTER, A. M., HECKEROTH, A. R. \& WEISS, L. M. (2000).

Toxoplasma gondii: from animals to humans. International Yournal for Parasitology 30, 1217-1258.

TERRY, R. S., SMITH, J. E., DUNCANSON, P. \& HIDE, G. (2001).

MGE-PCR: a novel approach to the analysis of

Toxoplasma gondii strain differentiation using mobile genetic elements. International Fournal for Parasitology 31, 155-161. 